\title{
The Evaluation of Swimming Sports Coaching Programs for Disabled Athletes in The National Paralympic Committee
}

\author{
Utomo $^{1,2}$, Yetti Supriyati ${ }^{1}$, Maruf Akbar ${ }^{1}$ \\ ${ }^{1}$ Program Studi Penelitian dan Evaluasi Pendidikan-Universitas Negeri Jakarta \\ ${ }^{2}$ Universitas Lambung Mangkurat
}

\begin{tabular}{l} 
INFO ARTIKEL \\
\hline Riwayat Artikel: \\
Diterima: $17-01-2020$ \\
Disetujui: $21-04-2020$ \\
\hline
\end{tabular}

Kata kunci:

program evaluation; swimming;

disability athletes;

$N P C$;

evaluasi program;

olahraga renang,

atlet disabilitas;

$N P C$

\author{
Alamat Korespondensi: \\ Utomo \\ Program Studi Penelitian dan Evaluasi Pendidikan \\ Universitas Negeri Jakarta \\ Jalan R. Mangun Muka Raya, Kota Jakarta Timur, Daerah Khusus Ibukota Jakarta 13220 \\ E-mail: utomo_pep11s3@mahasiswa.unj.ac.id; utomo.plb@ulm.ac.id
}

\begin{abstract}
Evaluation of swimming sports coaching programs for disabled athletes in the National Paralympic Committee (NPC) organization aims to assess the effectiveness of programs run by the South Kalimantan Province NPC by analyzing the role of each factor in accordance with the CIPP approach model. The CIPP model consists of four types of evaluations, namely: context evaluation, input evaluation, process evaluation. The data were analyzed using qualitative descriptive techniques. The results of the study were used for recommendations to all institutions/agencies/organizations in the field of sports in improving coaching for athletes with disabilities, especially in the field of swimming sports.
\end{abstract}

\begin{abstract}
Abstrak: Evaluasi program pembinaan cabang olahraga renang bagi atlet disabilitas pada organisasi National Paralympic Committee (NPC) bertujuan untuk mengkaji efektifitas program yang dijalankan oleh NPC Provinsi Kalimantan Selatan dengan menganalisis peran masing-masing faktor sesuai dengan model pendekatan CIPP. Model CIPP terdiri dari empat jenis evaluasi, yaitu: evaluasi konteks (context evaluation), evaluasi masukan (input evaluation), evaluasi proses (process evaluation). Data dianalisis menggunakan tehnik deskriptif kualitatif. Hasil penelitian dijadikan rekomendasi untuk bahan masukan kepada seluruh lembaga/instansi/organisasi bidang keolahragaan dalam meningkatkan pembinaan bagi atlet disabilitas, terutama dalam bidang olahraga renang.
\end{abstract}

Disabled athletes that attended swimming sport competition will reach good achievement if they are well-coached (Wijayanti dkk., 2017). The achievement reached by the disabled athletes is closely related with the coaching they obtained. Two elements within the coaching have been taken into account by Abayomi and Oyeniyi (2017). The two elements mentioned are organization and management. The research results indicated that schedule planning and equipment fulfillment serve as the contributing factors of the coaching success. In Indonesia, the disabled athletes are trained and organized under the National Paralympic Committee (NPC). NPC runs in three different level, Center Committee, Provincial Committee, and Regional Committee. The issues occurred within swimming sport has been examined by Yermahanova et al., (2016). The research entitled "Evaluation of Features of Development of Sports Way of Swimming of Students of Various Sports Specialization" reported that the students attinding the coaching were strongly influenced by the coaching metod, their swimming skills, and the skill of the coaches.

The problems regarding sport coaching for the disabled athletes were also reported by Wijayanti et al., (2017) in their research entitled "Sport Coaching for The Disabled Athletes in National Paralympic Committee of Salatiga in 2016" In addition, Dwi Gansar $\mathrm{S}$. W et al () revelaed several problems related to sport coaching for the disabled athletes. The problems found are: (1) The coaching program for the athletes has been running but some of the coaches did not arrange the coaching program in the written report, (2) The coaches play a vital role in the achievement of the athletes, however, most coaches have no official license, (3) the infrastructures and sport facilities in NPC Salatiga do not fulfill the coaching program, (4) the support from NPC Salatiga is not significant since some of the director board members are inactive. The research also found that the parents of the athletes give moral and spiritual support that strongly influence the performance of the athletes (Bas, 2016). 
Similar to the research results explained above, Nugroho et al., (2019) also report that (1) the coaches play a vital role in the athletes' performance, (2) the facilities and infrastructures in NPC should be supported by the central government to support the coaching and performances, (3) the support from the parents, both moral and spiritual, positively influence the performance. According to the above research results, the sport coaching for the disabled athletes, including swimming, needs to be improved. To achieve a good performance of swimming athletes, the committee needs to take into account the quality of the coaches, the coaching program, and the infrastructure and facilities.

According to the initial research, National Paralympic Committee of South Kalimantan has been successful in peparing their disabled swimming athletes. However, some obstacles still need to be resolved such as an athlete's regeneration. According to the report obtained, most of the swimming athletes are the formerly athletes. The absence of regeneration was occurred in the coaches formation. The human resource problem related to coaches formation remain unresolved. The entire coaches of swimming athletes are from general swimming athlete (non-disable). In addition, there is no special training of swimming coach for disabled athletes. Thus, the issues explained above hamper the process of ideal swimming sport coaching for disabled athletes conducted by NPC. Therefore, it requires further research and comprehensive study to observe the evaluation of swimming sport coaching programs conducted by NPC South Kalimantan to further create an ideal condition and improve the performance of coaching.

The purpose of this research was to identify the evaluation of swimming sport coaching program from disabled athletes in National Paralynpic Committee (NPC). This research further aims at observing how effective the programs run by the NPC South Kalimantan by analyzing the role of each factor through CIPP approach.

\section{METHOD}

This research employed qualitative research design and was a program evaluation research. This research aimed at evaluating the programs conducted by the NPC South Kalimantan for coaching a swimming sport of disabled athletes by employing CIPP model suggested and developed by Stufflebeam (2007). The components of CIPP evaluation model are illustrated in the following figure 1.

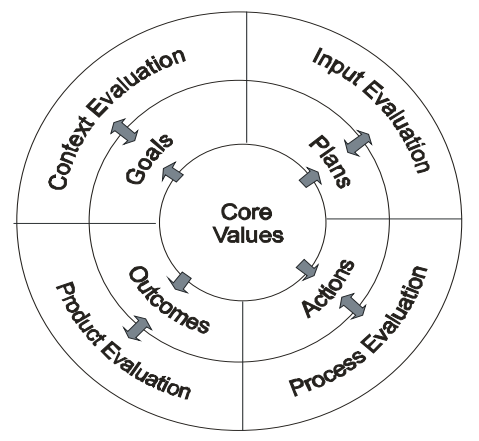

Figure 1: CIPP Model for Evaluation

The component of CIPP model for evaluation consisted of Context, Input, Process, and Product are explained in the following discussion (Yahaya, 2001). The component of context includes the identification of (a) the purpose of NPC South Kalimantan, (b) the legal basis of NPC South Kalimantan, (c) the need analysis of NPC South Kalimantan, and (d) the objective of adaptive coaching for disabled athletes conducted by NPC South Kalimantan.

The component of input includes (a) the identification of the program plan of adaptive sport coaching for disabled athletes in NPC South Kalimantan, (b) the identification of recruitment process of NPC South Kalimantan management members, (c) the identification of disabled athlete recruitment process in NPC South Kalimantan, (d) the identification of coaches recruitment process for disabled athlete in NPC South Kalimantan, (e) the identification of the infrastructures and facilities in NPC South Kalimantan, (f) the identification of financial support in NPC South Kalimantan, and $(\mathrm{g})$ the identification of the coordination between agencies performed by NPC South Kalimantan.

The component of process includes (a) the identification of program implementation consisting of physical, technical, mental, and tactical training on each adaptive sport branch in NPC South Kalimantan, (b) the identification of program try out on each adaptive sport branch in NPC South Kalimantan, (c) the identification of competition program in NPC South Kalimantan, (d) the identification of coaching competence improvement program in NPC South Kalimantan, (e) the identification of coaching supervision on adaptive sport branch for disabled athletes in NPC South Kalimantan. The component of product observed the outcomes in the form of the achievement reached by the disabled athletes in NPC South Kalimantan. 
The data collection techniques in this research were interview, questionnaires distribution, and documentation study. To analyze the obtained data, the researchers employed four stages of evaluation analysis, i.e: (1) data collection in accordance with the components of evaluation, (2) generating display data and performing data analysis by comparing the obtained data with the predetermined criteria, (3) providing an appropriate assessment, and (4) making decision as well as making suitable recommendation.

In this research, the researchers employed triangulation technique to scrutinize and verify the validity of the obtained data. Triangulation is defined as a data collection technique that combines various data collection techniques and data sources that have been obtained. If the researcher collects data by performing triangulation, the researcher actually collects the data and at the same time assesses the credibility of the data. Therefore, the data obtained will be more consistent, complete and evident. In this study, the researchers employed triangulation techniques. Triangulation techniques allow the researchers to use different data collection techniques to obtain data from the identical source. In this research, the researchers employed interviews, questionnaires and document study for the same data source simultaneously. Triangulation techniques can be visualized in figure 2 as follows:

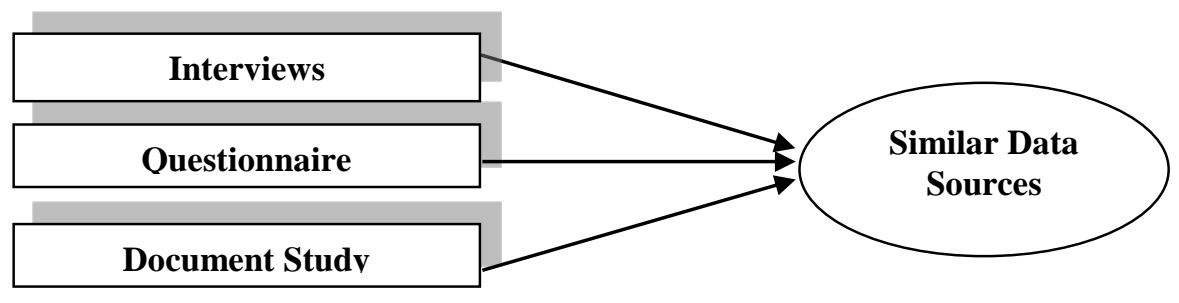

Figure 2. Triangulation Technique

\section{RESULTS \& DISCUSSION}

The evaluation of swimming sports coaching programs for disabled athletes in South Kalimantan Province conducted by the NPC of South Kalimantan Province can be described as follows:

\section{The Context of Component}

The effectiveness of the context in relation to the swimming sports achievement coaching program for disabled athletes in South Kalimantan at the NPC of the South Kalimantan Province produced qualitative data thus it was analyzed qualitatively. The focus of this research was directed at three important aspects or focus namely: (a) legal basis; program objectives; (b) needs analysis; and (c) targets towards fostering adaptive sports achievements for people with disabilities (Aziz et al, 2018).

There are a number of legal bases used for the basis of swimming sports coaching for disabled athletes, namely: Law No. 3 of 2005 concerning the National Sports System (SKN). In Law No. 3 of 2005, it is stated that competitive sports are sports that foster and develop athletes in a planned, tiered, and sustainable approach through competition to accomplish achievement with the support of sports science and technology. Article 4 states that national sports are aimed at maintaining and improving health and fitness, achievements, human qualities, instilling moral values and noble morals, sportsmanship, discipline, strengthening and fostering national unity and integrity, strengthening national resilience, and enhancing the nation's dignity, integrity, and honor.

Regional Regulation of the Province of South Kalimantan Number 10 of 2014 concerning the Implementation of Sports in the Fourth Section of the Development and Progress of Disability Sports Article 20 mentions that (1) the development of disability sports is carried out to improve health, self-confidence, and achievement; (2) the development of disability sports as referred to in paragraph (1) shall be carried out by sports organizations for disabilities; (3) the development of disability sports as referred to in paragraph (1) shall be carried out and held in the scope of educational, recreational and competitive sports; (4) The Regional Government through the regional apparatus that organizes government affairs in the field of sports implements the development of Sports for disabled athletes in the regional level.

Article 9 Amendment to the Articles of Association of the National Paralympic Committee of Indonesia (NPC) states that among the objectives of the formation of the NPC is to facilitate Indonesian disabilities to participate in national development through sports activities, to realize and develop the sports for disabled people who are more advanced, just, dignified and equal with the sports in general. 
The stipulation of Law No. 8 of 2016 concerning persons with disabilities also strengthens the development of competitive sports for persons with disabilities (Harimisa, 2017). Article 15 states that the sports rights for persons with disabilities include the right to: (a) perform sports activities; (b) obtain the equal achievement in sports activities; (c) obtain assistance in sports activities; (d) obtain accessible sports facilities and infrastructure; (e) choose and follow the branch of sport; (f) obtain direction, support, guidance, coaching, and development in sports; (g) perform as an athlete; (h) develop the sports industry; and (i) improve achievements and take part in the championship at all levels.

Related to the objective of organizing sports achievement coaching for persons with disabilities in the NPC of the Province of South Kalimantan, the Chairperson of the NPC of South Kalimantan stated that athletes with disabilities should strive to play an active role in the community through the field of adaptive sports. They are expected to be able to achieve in the sport competition at the regional, national, ASEAN, Asian and world level.

There are three types of athletes with disabilities who are targeted for swimming sports coaching in NPC of South Kalimantan, they are: 18 physical disability athletes, 4 visual impairment athletes and 1 intellectual disability athlete. The total number of athletes with disabilities under the coaching programs of NPC of South Kalimantan are 23 athletes.

\section{The Component of Input}

The entire programs of swimming sport coaching under the supervision of NPC of South Kalimantan for the athletes with disabilities are funded by the provincial government of South Kalimantan through grant funding scheme of Sport and Youth Office of South Kalimantan. From year to year, the provincial government of South Kalimantan provides financial supports to the entire coaching programs. The current financial support focuses on preparing the upcoming competition, The 2020 National Paralympic Event in Papua. To reach good achievements in the competition, the NPC of South Kalimantan gives paramount support to the athletes. Several supports given are: providing financial support for accommodation for the management, coaches, and the athletes during provincial and national events, attending tryout in some regions, conducting training for the coaches, conducting regional coaching program, and establishing regional coaching monitoring team.

The recruitment of athletes with disabilities for swimming sport is continuously conducted. In addition to conduct a training and coaching for competing in West Java National Paralympic Event 2016, the NPC of South Kalimantan also recruited some new athletes through a relatively tight selection. The athletes attending the selection were recommended by the local NPC (city or regency level) within South Kalimantan. The following Table 1 reports the recapitulation of the athletes with disabilities to attend Regional Coaching Program 2020.

Table 1. The Recapitulation of Athletes with Disabilities of Swimming Sport (source: Swimming Sport Coaching Management of NPC of South Kalimantan 2020)

\begin{tabular}{rllll}
\hline No & Disabilities Category & Total & Classification & City/Regency \\
\hline 1 & Physical disability & 18 people & S5-S10 & Banjarmasin City: 10 people; Banjarbaru City: 4 people; Balangan \\
2 & Visual impairment & 4 people & S11-S13 & Regency: 3 people; Tapin Regency: 3 people; Batola Regency: 2 \\
3 & Intellectual disability & 1 people & S14 & people; and Banjar: 1 people \\
\hline
\end{tabular}

The recruitment of swimming sport coaches was also conducted. Most of the coaches who train the athletes are the exathletes of National Sport Event and they are assisted by the coach assitants. There are three coaches and one coach assistant of swimming sport that obtained an A-grade certificate (International), a B-grade certificate (National), and D-grade certificate for coaching and they are assisted by one coach assistant. Although the coaches obtained a general certification for swimming sport athlete, they are able to perform a coaching to the athletes with disabilities. They obtained an additional training how to perform a coaching for athletes with disabilities which was conducted by the NPC of South Kalimantan.

To conduct a coaching for the athletes with disabilities, the committee use Hasanudin Sport Center Building in Banjarmasin. Hasanudin Sport Center building is managed by the provincial government of South Kalimantan through Sport and Youth Department Office. Commonly, the committee use three parts of building for conducting coaching program, they are swimming pool, fitness center, and athlete's dormitory (see Figure 3). The provincial government built Hasanudin Sport Center building for public use. It means that during the development of the building, it did not consider the accessibility for people with disabilities. However, the dormitory buildings have provided an access for people with disabilities in the form of special lane for wheelchair. 


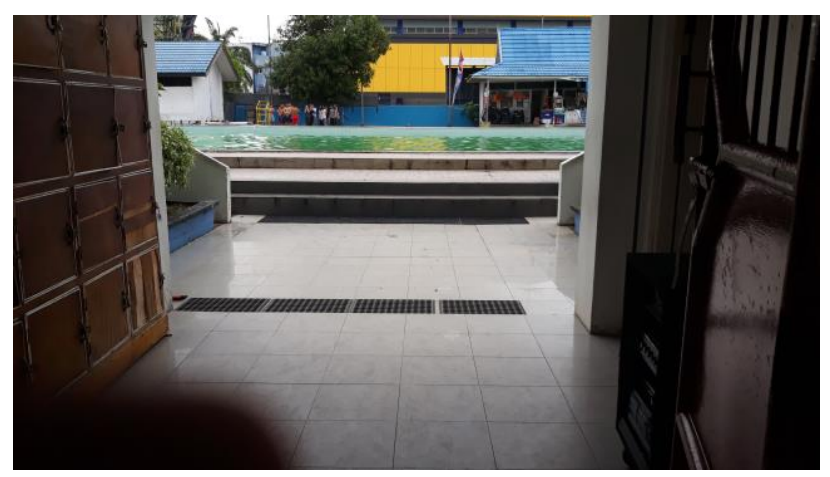

Figure 3. Swimming Pool in Hasanudin Sport Center in Conducting Coaching Program for Athletes with Disabilities

The success of sport coaching program for athletes with disabilities was obtained from a good cooperation established among the related stakeholder: the NPC of South Kalimantan, the NPC of each city and regency, and Sport and Youth Department Office of South Kalimantan.

\section{The Component of Process}

The implementation of swimming sport coaching program for athletes with disabilities by the NPC of South Kalimantan was started by conducting open recruitment of athletes with disabilities from any cities and regencies within South Kalimantan province. Most of the athletes with disabilities who followed the recruitment have acquired basic skill of swimming, but some of them did not have the basic skill of swimming. If during the recruitment they showed a good potency in swimming, the committee will consider them to join the swimming sport team. The swimming sport coaching program conducted for athletes with disabilities focuses on four major training, they are: physical training, technical training, tactical training, and psychological assistance. The coaches train the athletes with disabilities some general swimming styles such as front crawl, backstroke, breaststroke, and butterfly stroke.

The swimming sport coaching program was divided into two stages: routine coaching program after the athletes with disabilities attending National Paralympic Event and concentrated coaching program to prepare the athletes with disabilities for attending the upcoming National Paralympic Event. The National Paralympic Event is held every four years. The routine coaching program is commonly conducted three years and the concentrated coaching program is commonly conducted one year before attending the National Paralympic Event. For instance, after the athletes with disabilities attending The XV National Paralympic Event in 2016 in Bandung, East Java, they followed routine coaching program three years; in 2017, 2018, and 2019. Then, the athletes with disabilities followed the concentrated coaching program in 2020. The following Table 2 shows the data regarding the coaching program, both routine and concentrated.

Table 2. Coaching Program for Swimming Sport (source: Swimming Sport Coaching Management of NPC of South Kalimantan 2020)

\begin{tabular}{|c|c|c|c|c|}
\hline \multirow[t]{2}{*}{ Training } & \multicolumn{3}{|c|}{ Rountine Coaching } & Concentrated Coaching \\
\hline & Year I & Year II & Year III & Year IV \\
\hline $\begin{array}{l}\text { Physical, Technical, Tactical, and Psychological } \\
\text { assistance }\end{array}$ & $\begin{array}{l}3 \mathrm{x} \quad \mathrm{a} \\
\text { week }\end{array}$ & $\begin{array}{lr}3 \mathrm{x} & \mathrm{a} \\
\text { week }\end{array}$ & $\begin{array}{ll}6 \quad \mathrm{x} & \mathrm{a} \\
\text { week }\end{array}$ & $\begin{array}{ll}10 \mathrm{x} \text { a week } \\
-\quad \text { Morning } 6 \text { x (Monday - Saturday) } \\
-\quad \text { Evening } 4 \text { x (Monday, Tuesday, Thrusday, } \\
\quad \text { Friday) }\end{array}$ \\
\hline
\end{tabular}

The routine coaching program aims at maintaining the performance achieved by the athletes and maintain the physical fitness of the athletes with disabilities. According to the coaches, if the athletes did not maintain the sustainability of the training, they need to be trained from the beginning. This condition makes the athletes with disabilities are not able to maintain their performance. The routine coaching program also aims at preparing the athletes with disabilities before attending another competition, provincial or national competition.

The intensity percentage of each training aspect (technical, tactical, ) during the concentrated coaching program is changing due to the days remaining before the competition begins. The purpose of concentrated coaching program is to prepare the athletes with disabilities to reach good performance and achievement during the upcoming National Paralympic Event. During the coaching program, the coaches carefully select and determine the swimming styles of the athletes with disabilities which based on their best 
performance and disability conditions. This is one of the strategies to achive the medals in the competition, particularly the strategy to achieve gold medal. Table 3 below indicates the intensity percentage of each training aspect for the athletes with disabilities during the concentrated coaching program before competing in the XVI National Paralympic Event in Papua.

Table 3. The Intensity Percentage of Each Training Aspect for The Athletes With Disabilities (source: Swimming Sport Coaching Management of NPC of South Kalimantan 2020)

\begin{tabular}{|c|c|c|c|c|c|c|c|c|c|c|c|}
\hline Training & $\begin{array}{c}\text { Month } \\
1\end{array}$ & $\begin{array}{c}\text { Month } \\
2\end{array}$ & $\begin{array}{c}\text { Month } \\
3\end{array}$ & $\begin{array}{c}\text { Month } \\
4\end{array}$ & $\begin{array}{c}\text { Month } \\
5\end{array}$ & $\begin{array}{c}\text { Month } \\
6\end{array}$ & $\begin{array}{c}\text { Month } \\
7\end{array}$ & $\begin{array}{c}\text { Month } \\
8 \\
\end{array}$ & $\begin{array}{c}\text { Month } \\
9\end{array}$ & $\begin{array}{c}\text { Month } \\
10\end{array}$ & $\begin{array}{c}\text { Month } \\
11\end{array}$ \\
\hline Physical & $45 \%$ & $50 \%$ & $50 \%$ & $55 \%$ & $40 \%$ & $30 \%$ & $15 \%$ & $30 \%$ & $30 \%$ & $30 \%$ & $20 \%$ \\
\hline Technical & $45 \%$ & $40 \%$ & $30 \%$ & $25 \%$ & $15 \%$ & $20 \%$ & $15 \%$ & $30 \%$ & $30 \%$ & $30 \%$ & $20 \%$ \\
\hline Tactical & $10 \%$ & $10 \%$ & $10 \%$ & $10 \%$ & $15 \%$ & $30 \%$ & $35 \%$ & $20 \%$ & $20 \%$ & $20 \%$ & $30 \%$ \\
\hline $\begin{array}{l}\text { Psychological } \\
\text { assistance }\end{array}$ & $10 \%$ & $10 \%$ & $10 \%$ & $10 \%$ & $30 \%$ & $20 \%$ & $35 \%$ & $20 \%$ & $20 \%$ & $20 \%$ & $30 \%$ \\
\hline
\end{tabular}

The process of swimming sport coaching program for the athletes with disabilities requires a complicated adjustment and adaptation to accommodate a diverse disability condition of each athlete. As stated by Soegiana (2018), the communication pattern to the athletes with disabilities needs to be adjusted based on the disability of each athlete. The training material for the athletes with disabilities are most likely similar to the general training, but during the implementation, the coaches need to carefully adjust how to communicate and train them based on the condition since they have particular limitation.

Several adjustments that are made by the coaches during the training program are as follows: during the physical fitness training by using gym equipment, the coaches do not force them to use the equipment. They are allowed to use any kind of equipment which meet their condition. For instance, if the athlete only has one leg, he/she could choose not to focus on the leg physical fitness that require both legs. The coaches instruct them to use the equipment that allows them to use only a single leg. In addition, the coaches do not force the athletes to choose one style that does not meet their condition, although all athletes are required to acquire all skills of swimming. For instance, if the athlete only has a one leg or the legs are weak, they can choose swimming styles that do not force their legs. The swimming styles of the athletes are based on the disability conditions of each athlete and their strength. In addition, the athletes do not always need to take the longest swimming number. Another adjustments are made to the athletes with visual impairement. During the training, the coaches use rubber rope as a sign that they are closed to the finish line (see Figure 4). The rubber rope is installed a half meter before the finish line. The installation of rubber rope aims at assisting the athletes with visual impairement that they are just closed to the finish line to avoid any injury due to hard concussion from the finish line wall. During the competition, the committee usually use head sign. The head sign is made of a stick and rubber. Before the athletes with visual impairment reach the finish line, about one metre, the referee will touch the head of the athletes with visual impairement as a sign that they are just closed to the finish line. The purpose is to avoid serious injury when the athletes reach the finish line wall, a hard concussion.

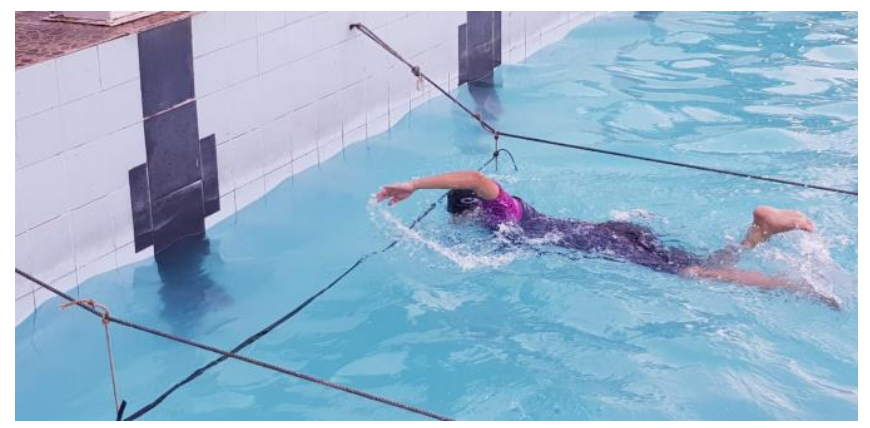

Figure 4. The Installation of "Rubber Rope Sign" as One of The Adjustments for The Athletes with Visual Impairment 


\section{The Component of Product}

The swimming sport coaching program for the athletes with disabilities in the NPC of South Kalimantan from year to year indicates an improvement, particularly in terms of medal achievement. Table 4 below shows the medal achievement in three years.

Table 4. The Medal Achievement Recapitulation (source: Swimming Sport Coaching Management of NPC of South Kalimantan 2020)

\begin{tabular}{lccccccc}
\hline \multirow{2}{*}{ Event } & \multirow{2}{*}{ Rank } & \multicolumn{3}{c}{ Total of Medals } & \multicolumn{3}{c}{ Medals from Swimming Sport Branch } \\
\cline { 3 - 8 } & Gold & Silver & Bronze & Gold & Silver & Bronze \\
\hline $\begin{array}{l}\text { Porcanas XIII } \\
\text { Kaltim 2008 }\end{array}$ & 11 & 9 & 5 & 3 & 8 & 3 & 0 \\
$\begin{array}{l}\text { Peparnas XIV } \\
\text { Riau 2012 }\end{array}$ & 6 & 24 & 29 & 24 & 14 & 9 & 5 \\
$\begin{array}{l}\text { Peparnas XV } \\
\text { Jabar 2016 }\end{array}$ & 6 & 33 & 23 & 22 & 15 & 13 & 6 \\
\hline
\end{tabular}

In addition, the athletes with disabilities obtained a bonus in the form of financial support from the provincial government of South Kalimantan. In line with the findings of Zuhriah et al., (2019), one of the strategies to improve the performance of the athlete is by offering them a bonus in the form of money if they achieved good performance or medals during the competition. The bonus given to the athletes with disabilities are equal to the bonus given to the general athletes of National Olympic Events.

Furthermore, the swimming sport coaching program conducted by the NPC South Kalimantan also achieved good performance in some national competition, for instance a National Competition in Solo Central Java. Some athletes also achieved good performance in the higher level of competition (APG) and were selected to attend concentrated coaching program in the national level (see Table 5 and 6).

Table 5. The Data of Swimming Athletes with Disabilities Attending APG in 2017 Malaysia Dan in 2018 Jakarta (source: Swimming Sport Coaching Management of NPC of South Kalimantan 2020)

\begin{tabular}{|c|c|c|c|c|c|c|c|}
\hline \multirow{2}{*}{ No } & \multirow{2}{*}{ Name } & \multicolumn{3}{|c|}{ APG 2017 Malaysia } & \multicolumn{3}{|c|}{ APG 2018 Jakarta } \\
\hline & & Gold & Silver & Bronze & Gold & Silver & Bronze \\
\hline 1 & Nor Aimah & 1 & - & 1 & - & - & - \\
\hline 2 & Suriansyah & 3 & - & 1 & - & - & - \\
\hline 3 & Iberamsyah & - & - & - & - & - & 1 \\
\hline \multirow[t]{2}{*}{4} & Riyanti & - & 1 & 1 & - & - & - \\
\hline & Total & 4 & 1 & 3 & 0 & 0 & 1 \\
\hline
\end{tabular}

Table 6. The Medals Achieved during NPC Indonesia for Swimming in Solo 26-27 Oktober 2019 (source: Swimming Sport Coaching Management of NPC of South Kalimantan 2020)

\begin{tabular}{clccc}
\hline \multirow{2}{*}{ Rank } & \multirow{2}{*}{ Province } & \multicolumn{3}{c}{ APG 2017 Malaysia } \\
\cline { 3 - 5 } & & Gold & Silver & Bronze \\
\hline 1 & Central Java & 12 & 11 & 6 \\
2 & South Kalimantan & 11 & 7 & 1 \\
3 & West Java & 10 & 3 & 5 \\
$4-22$ & $\ldots \ldots \ldots \ldots \ldots \ldots \ldots \ldots \ldots$. & $\ldots \ldots$. & $\ldots \ldots$. & $\ldots \ldots \ldots$ \\
\hline \multicolumn{5}{c}{} \\
\hline
\end{tabular}

The athletes with disabilities who achieved good performance during APG or Asian Paragames or in Paragames have a chance to register themselves as Civil Servant through through sport achievement track if they meet the requirements, particularly the requirements regarding age limitation and the educational background. This aims at motivating the athletes with disabilities to achieve good performance in the competition (Rozi, 2012; Setyaningrum, 2018). Unfortunately, the three athletes with disabilities from swimming sport branch could not pass the passing grade set by the central government, although the passing grade was lower than 
the general track. Table 7 below illustrates the recapitulation of Civil Servant selection results for the athletes with disabilities who achieved good performance in APG 2017 Malaysia.

Table 7. The Recapitulation Of Civil Servant Selection Results For The Athletes With Disabilities (source: Swimming Sport Coaching Management of NPC of South Kalimantan 2017)

\begin{tabular}{clc}
\hline No & \multicolumn{1}{c}{ Name } & Results \\
\hline 1 & Ahmad Fauzi & Passed \\
2 & Warmia & Not Passed \\
3 & Yahya & Passed \\
4 & Nor Aimah (swimming) & Not Passed \\
5 & Suriansyah (swimming) & Not Passed \\
6 & Riyanti (swimming) & Not Passed \\
7 & Hermanudin & Not Passed \\
8 & M. Yahya Hernanda & Not Passed \\
9 & Triagus Arief Rakhman & Passed \\
\hline
\end{tabular}

Six athletes of swimming sport branch with disabilities from the NPC of South Kalimantan were selected to attend national training program in Solo to prepare for APG (Asian Paragames) in Philipine 2020. The six athletes of swimming sport with disabilities who were selected are Suriansyah, Mulyadi, Ahmad Zaini, Nur Aimah, Riyanti, and Fitria.

Swimming sports training for athletes with disabilities in the NPC of South Kalimantan is good enough in terms of context, input, process, and product. In terms of context, the NPC of South Kalimantan already has a legal basis and clear direction of purpose. This is in accordance with the mandate of Law No. 3 of 2005 concerning SKN, Law No. 8 of 2016 concerning Persons with Disabilities, South Kalimantan Provincial Regulation number 10 of 2014 concerning Organizing sports, and also the Statutes established by the Central NPC.

In terms of input, the the NPC of South Kalimantan has tried to fulfill the components needed for successful swimming sports development for disabled athletes. The recruitment of new athletes as a step forward for the next generation of swimming athletes with disabilities has also been carried out. A number of 23 disabilities athletes are currently coached, nine athletes are a new generation, the remaining 18 athletes are the former athletes who have performed well in previous competition. The number of new athletes is not as much as the former athletes, but this has been an effort to regenerate. The former athletes who have already performed well are certainly needed to strengthen the achievement of medal gains at the next event. The obstacle faced in recruiting new athletes is that there are still obstacles for the selection of persons with disabilities and the selection of sports talent (Pratama, 2019).

According to data from the Statistics Bureau, the number of persons with disabilities was around 10\% of the population (Sari, 2019). Financial support for the training of athletes with disability of swimming sports is almost entirely supported by the Provincial Government of South Kalimantan. This is in accordance with the mandate of Regional Regulation number 10 of 2014 Article 4 paragraph 1 and paragraph 3 which mention that (1) The Regional Government is obliged to conduct training and development of sports in the region in accordance with its authority and responsibilities (Susanti, 2019). (3) The responsibilities of the regional government as referred to in paragraph 1 include the development and development of sports, sports personnel and sports organizations, the provision of sports funds, the preparation of methods for the development and progress of sports, the provision of sports infrastructure and facilities, as well as the awards in sports. This is in accordance with the opinion of Harahap (2018) in his research on government policy in improving the achievements of national athletes.

The recruitment of coach was taken from the former swimming athletes and had received training from international, national and regional trainers. There are three coaches and one assistant tcoaches to train 23 athletes with disabilities thus the coach ratio is satisfied the standard: 1 coach to 5-6 athletes. This is in accordance with the ratio of handling people with disabilities, namely 1 people handling 5 children with special needs (Rofiah \& Kurniawan, 2017).

The facilities and infrastructure used are sufficient, only the accessibility is not yet well available. This has been stipulated in Law No. 28 of 2002 concerning building requirements. Swimming pool facilities and infrastructure should meet accessibility standards for people with disabilities (Nadya, 2017). There are some elements that need to be provided including plane for wheelchair users, guiding block (directional sign for visually impaired athletes), parking lots and special toilets for people with disabilities. Swimming pool is included in the category of public facilities and it must follow the requirements specified by applicable laws and regulations. 
The swimming coaching process for athletes with disabilities has been going well. The most prominent elements in the coaching process is that: it is carried out continuously thus the athlete's achievements are well maintained. The coaches have adopted adjustment to the conditions of athletes with disabilities. This is consistent with the theory of social models popularized by a disabled academic named Mike Oliver. One social model theory is that the environment must be able to adapt to people with disabilities (Oliver, 2017; Burholt et al., 2017). With this adjustment, athletes with disabilities will develop well.

On the component of product, the results of the study showed that the achievements swimming athletes with disabilities in the NPC of South Kalimantan Province were quite encouraging. The achievements of athletes with disabilities receive awards and promotions for participating in higher events. This according to Maslow said that these needs include the need for the desire to be respected, valued for one's achievements, recognition of one's abilities and expertise and the effectiveness of one's work (Taormina \& Gao, 2013). Awards will increase motivation to continue to excel so that athletes are entitled to participate in higher events.

\section{CONCLUSION}

The results of the evaluation of swimming sports training programs for athletes with disabilities in the National Paralympic Committee (NPC) of South Kalimantan in terms of context, input, process, and products have been quite successful. The coaching process achieved several awards and proud achievements.

\section{REFERENCES}

Abayomi, B. O., Oyeniyi, P. O., \& Ainazx, O. O. (2017). Evaluation of Organization and Administration of Intramural Sports Programmes in Secondary Schools in Ibadan Metropolis. Pedagogical Research, 2(1), n1. http://doi.org/10.20897/pedre.201703. 2017

Aziz, S., Mahmood, M., \& Rehman, Z. (2018). Implementation of CIPP Model for Quality Evaluation at School Level: A Case Study. Journal of Education and Educational Development, 5(1), 189-206.

Bas, M. (2016). The Evaluation of Motivation and Sport Education Relationship. Journal of Education and Training Studies, 4(12), $27-29$.

Burholt, V., Windle, G., Morgan, D. J., \& CFAS Wales Team. (2017). A Social Model of Loneliness: The Roles of Disability, Social Resources, and Cognitive Impairment. The Gerontologist, 57(6), 1020-1030.

Daniel L. Stufflebeam \& Shinkfield, J. Anthony. (2007). Evaluation, Theory, Models \& Applications. Sanfransisco: John Wiley \& Sons.

Harahap, I. H. (2019). Kebijakan Pemerintah dalam Meningkatkan Prestasi Atlet Nasional. Journal of Entrepreneurship, Management and Industry (JEMI), 1(4), 189-198.

Harimisa, D. (2017). Tindak Pidana Menghalang-Halangi atau Melarang Hak Penyandang Disabilitas Menurut Pasal 145 UndangUndang Nomor 8 Tahun 2016 Tentang Penyandang Disabilitas. LEX PRIVATUM, 5(5), 132—138

Nadya, J. (2017). Redesain Interior Terminal Giwangan yang Memenuhi Kebutuhan Aksesibilitas Penumpang Difabel. Disertasi tidak diterbitkan. Institut Seni Indonesia Yogyakarta, Indonesia.

Nugroho, R. S., Kristiyanto, A., Purnama, S. K. (2019, April). Faktor Keberhasilan Atlet NPC Indonesia Dalam Meraih Medali pada Ajang Multi Event Asian Paragames 2018 di Jakarta. Proceedings of the National Seminar on Women's Gait in sports towards a healthy lifestyle (1-6). Surakarta, Indonesia: Universitas Tunas Pembangunan.

Oliver, M. (2017). Defining Impairment and Disability: Issues at Stake. In Disability and Equality Law (pp. 3-18). Routledge.

Pratama, K. Y. (2019). Implementasi Kebijakan Pembinaan Olahraga Anak Berkebutuhan Khusus di Kota Yogyakarta. Spektrum Analisis Kebijakan Pendidikan, 8(3), 245-250.

Rofiah, N. H., \& Kurniawan, M. R. (2017). Kesiapan Guru dalam Pelaksanaan Wajib belajar 12 Tahun di Sekolah Inklusi. URECOL, 343-348.

Rozi, F. (2012). Motivasi Atlet National Paralympic Committe (NPC) Indonesia Provinsi Sumatera Utara pada Cabang Olahraga Atletik Dalam Persiapan Peparnas XIV di Riau Tahun 2012. Disertasi tidak diterbitkan. Universitas Negeri Medan, Medan.

Sari, L. C. (2019). Peran Bimbingan Keagamaan Dalam Membentuk Kemandirian Anak Disabilitas. Disertasi tidak diterbitkan. UIN Sunan Gunung Djati Bandung, Indonesia.

Setyaningrum, M. L. (2018). Motivasi Berprestasi Pada Atlet Penyandang Tunadaksa yang Mengikuti Paralympic di Tenggarong. Psikoborneo, 6(3), 510-519.

Soegiana, H. P., Yuliana, N., \& Nesia, A. (2018). Komunikasi Instruksional Pelatih dan Atlet Tenis Meja Tunanetra Kota Bekasi. Disertasi tidak diterbitkan. Universitas Sultan Ageng Tirtayasa, Indonesia.

Susanti, T. (2019, March). Evaluasi Program Pembinaan Olahraga Pencak Silat di Pusat Pendidikan dan Latihan Pelajar Daerah (PPLPD) Musi Banyuasin. In Seminar Nasional Olahraga (pp. 309-317). 
Taormina, R., \& Gao, J. (2013). Maslow and the Motivation Hierarchy: Measuring Satisfaction of the Needs. The American Journal of Psychology, 126(2), 155-177. doi:10.5406/amerjpsyc.126.2.0155

Wijayanti, D. G, S,, Soegiyanto, S., \& Nasuka, N. (2017). Pembinaan Olahraga untuk Penyandang Disabilitas di National Paralympic Committee Salatiga. Journal of Physical Education and Sports, 5(1), 17-23.

Yahaya, A. (2001, July). The Using of Model Context. Input, Process and Products (CIPP) in Learning Programs Assessment. In International Conference on Challenges and Prospects in Teacher Education (pp. 1-4).

Yermahanova, A., Nurmakhambetova, D., Bozhig, Z., \& Imanbetov, A. (2016). Evaluation of Features of Development of Sports Way of Swimming of Students of Various Sports Specialization. International Journal of Environmental and Science Education, 11(18), 10895-10904.

Zuhriyah, A., Kristiyanto, A., \& Purnama, S. K. (2019). Analisis Strategi Pembinaan Prestasi Atlet Penyandang Disabilitas di Kabupaten Klaten. The 9th University Research Colloqium (Urecol), 9(5). 